\title{
Strategic transborder environmental assessment for power generation in the Baja California, México and California, USA border region
}

\author{
M. Quintero-Núñez ${ }^{1}$, E. C. Nieblas-Ortíz ${ }^{2}$, N. Velásquez-Limón ${ }^{1}$ \\ \& O. R. García-Cueto ${ }^{1}$ \\ ${ }^{1}$ Instituto de Ingeniería, Universidad Autónoma de Baja California, \\ México \\ ${ }^{2}$ Secretaria de Protección Ambiental del Estado de Baja California, \\ México
}

\begin{abstract}
The foreign investment to generate power has increased in the state of Baja California, Mexico, based on the construction of private power plants near the border. Less compliance to environmental regulations and procedures in Mexico compared with those in the USA, encourage the interest of investors in the construction of this type of plants. Non-attainment of the air quality regulations proposed by both federal administrations has been detected in Tijuana-San Diego and Mexicali-Imperial. It is suggested the creation of a binational management mechanism for the common airshed, which would develop methods to establish a procedure for the strategic transborder environmental assessment, allowing the introduction of new industries without an increment in the volume of emissions or more deterioration in the air quality of the area. The establishment of policies such as net zero emissions, a common airshed between two border cities, the use of the Best Available Technology (BAT) to minimize emissions to the atmosphere and emission reduction credit are very much recommended.
\end{abstract}

Keywords: common airshed, strategic transborder environmental assessment, Mexicali-Imperial. 


\section{Introduction}

The main objective of this work is to present a panorama of the power generation and its impacts in the air quality at the border region south of California, USA and north of Baja California, Mexico, as well as to proposed a bi-national mechanism for the management of the common airshed, and the adoption of an strategic transborder environmental assessment that leads to the improvement of the air quality in the region.

The electric sector in North America is implementing changes without precedent. It is foreseen the restructure of the market, the gradual evolution of the generation, and the extension and integration of transmission grids that connect various regions to widen and modified the commercial patterns between Canada, USA and Mexico [1].

The importations and exportations of electricity between Mexico and USA have been concentrated mostly in the California-Baja California region. However there are signs that this pattern of transborder commerce will be modified in a near future and that Mexico may become a net power exporter to the American market. At the present time 1,000 MWhr are exported to California from power plants built and operated by foreign investment under a mutual agreement with the Federal Electricity Commission (CFE by its acronym in Spanish). The California-Baja California border region is ideal for the development of new power infrastructure, and needless to mention that Baja California is seen by international investors dedicated to power generation and liquefied natural gas plants, as an excellent site for projects oriented to serve the California energy market [2].

On the other hand the adverse effects of the generation and distribution of electric energy on the environment are not an easy task to manage, and it is even more difficult at the border region. Natural physical environment and its processes do not respect political borders, internally and amongst countries. Since there are not physical barriers to modify or prevent nature from its effects, the inhabitants of both sides of the USA/Mexico border share the same airshed, and air quality problems due to industrial, commercial, and social operations, and this region is the fine example of the encounter of nature and technology and its effects on the environment.

The inhabitants of the area [3] are commonly exposed to levels of contamination of air that threaten their health. The ozone $\left(\mathrm{O}_{3}\right)$, the suspended particles $\left(\mathrm{PM}_{10}\right.$ and $\left.\mathrm{PM}_{2.5}\right)$, the carbon monoxide $(\mathrm{CO})$, the sulphur dioxide $\left(\mathrm{SO}_{2}\right)$, the carbon dioxide $\left(\mathrm{CO}_{2}\right)$ and the hydrogen sulphide $\left(\mathrm{H}_{2} \mathrm{~S}\right)$ are some of the atmosphere pollutants that concern the communities of this border.

For many years, the USA and Mexico governments have been involved in mutual cooperation efforts to protect the environment and the natural resources of their common border. There have been numerous agreements that have established a guide for the development of strategies and actions to preserve and improve the quality of the environment in benefit of both of them. In 1983 the Agreement for the Protection and Improvement of the Environment of the Border Region was signed, better known as the La Paz Agreement, as it was 
signed in that city; ever since, has been the formal base for the subsequent efforts of mutual cooperation.

The US Environmental Protection Agency (USEPA) and the Secretary of the Environment and Natural Resources of Mexico (SEMARNAT by its acronym in Spanish) have classified this region as "non-attainment", e.g. they have not complied with the National Ambient Air Quality Standards (NAAQS), for some of the reference pollutants [3].

\section{Population growth}

In order to provide an idea of the magnitude of the new schemes of commerce between the USA and Mexico, produced from a more open and competitive electricity market, it is important to stress out that their border region is one of the most dynamic and complex in the world [4].

From the geopolitical viewpoint, ninety percent of the border population resides in 14 paired, inter-dependent sister cities distributed in California, Arizona, New Mexico and Texas, in the USA; Baja California, Sonora, Chihuahua, Nuevo Leon, Coahuila and Tamaulipas in Mexico (Fig. 1). The border has a length of $3,141 \mathrm{Kms}$, from the Pacific Ocean up to the Gulf of Mexico. At the present time it has a population of 12 million people, figure that will double in the year 2020, thus it is amongst the regions with the fastest growth in North America.

Somehow, the CA/BC border region is an area of special relevance; both states include nearly $42 \%$ of the total population settled in such region (Fig. 2). On the American side are located the San Diego and Imperial Valley counties,

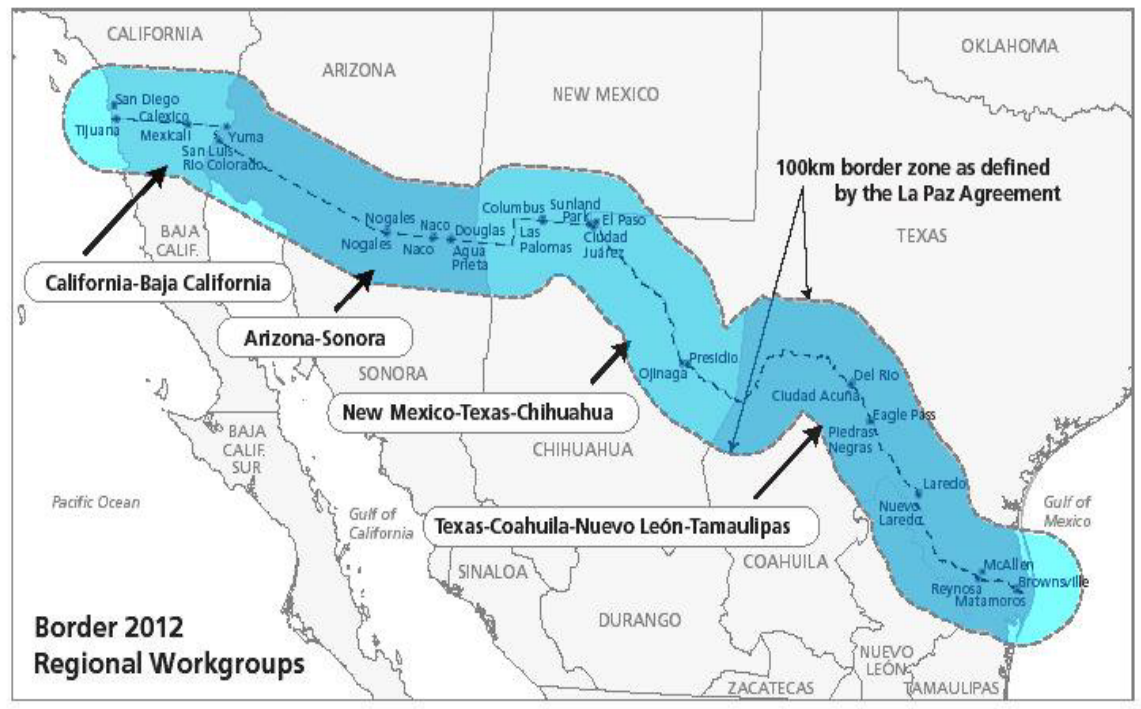

Figure 1: $\quad$ Border region between Mexico and the USA. 
while on the Mexican side the municipalities of Tijuana, Rosarito, Tecate and Mexicali [4].

The actual population of that area is 5.5 million people. However, for the year 2020 , is estimated that will rise to 9.4 million (see Fig. 2). In the San DiegoTijuana region will reach 7.6 million in the next 13 years. It is expected that the population growth index, together with the increment in the industry, will keep the demand of electricity high in the next 10 years; in Baja California will have a growth rate of 6-7\% annual and 3\% in San Diego, CA.

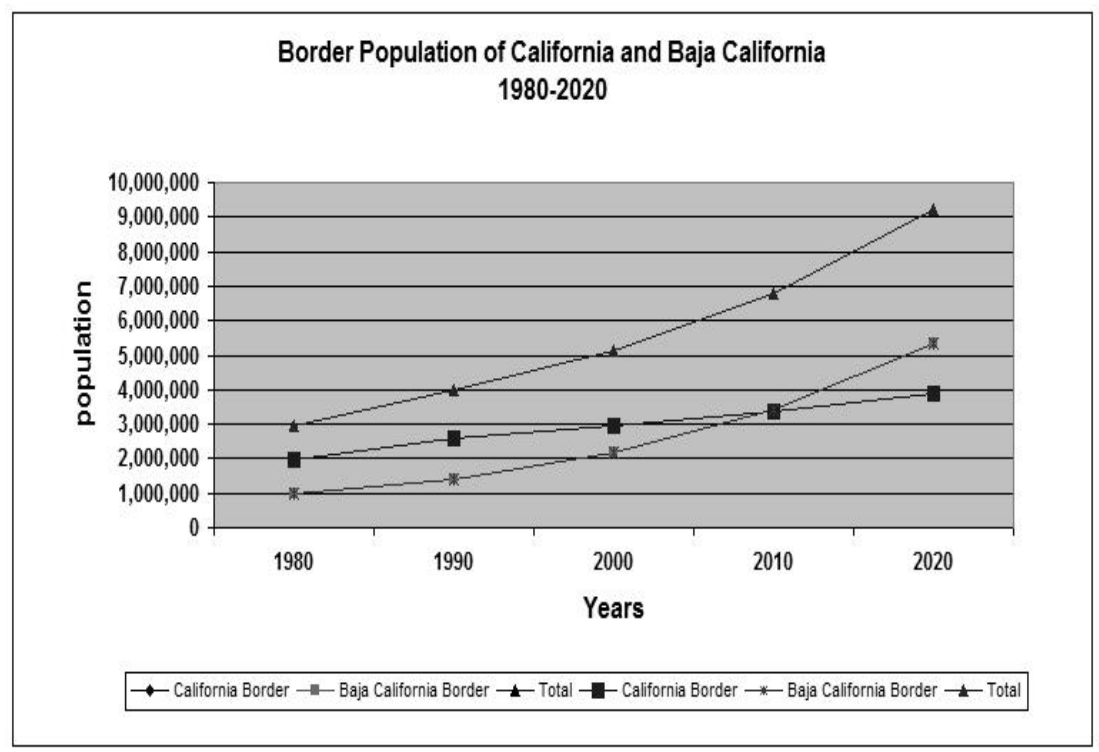

Figure 2: $\quad$ Population growth and projections at the California-Baja California border region (Source: XII Censo General de Población, INEGI, 2000).

\section{Power generation at the $\mathrm{CA}$-Baja California border}

In California and Baja California, the energy issues are special, due to the complex situation that faces the former in that subject, and that the latter is physically isolated from the rest of the Mexico. In fact, the Baja California electricity transmission grid is not connected to the national system.

Nowadays, the electric infraestructure in Baja California (see Fig. 3) is integrated by four power generating plants, several small plants and an adequate system of transmission lines. The grid is connected to San Diego (USA) using four lines of 230 kilovolts (KV), one of them is located in Tijuana, and three in Mexicali, the four grids belong to American companies: Sempra, Intergen and San Diego Gas \& Electric. 


\section{POWER GENERATION IN BAJA CALIFORNIA}

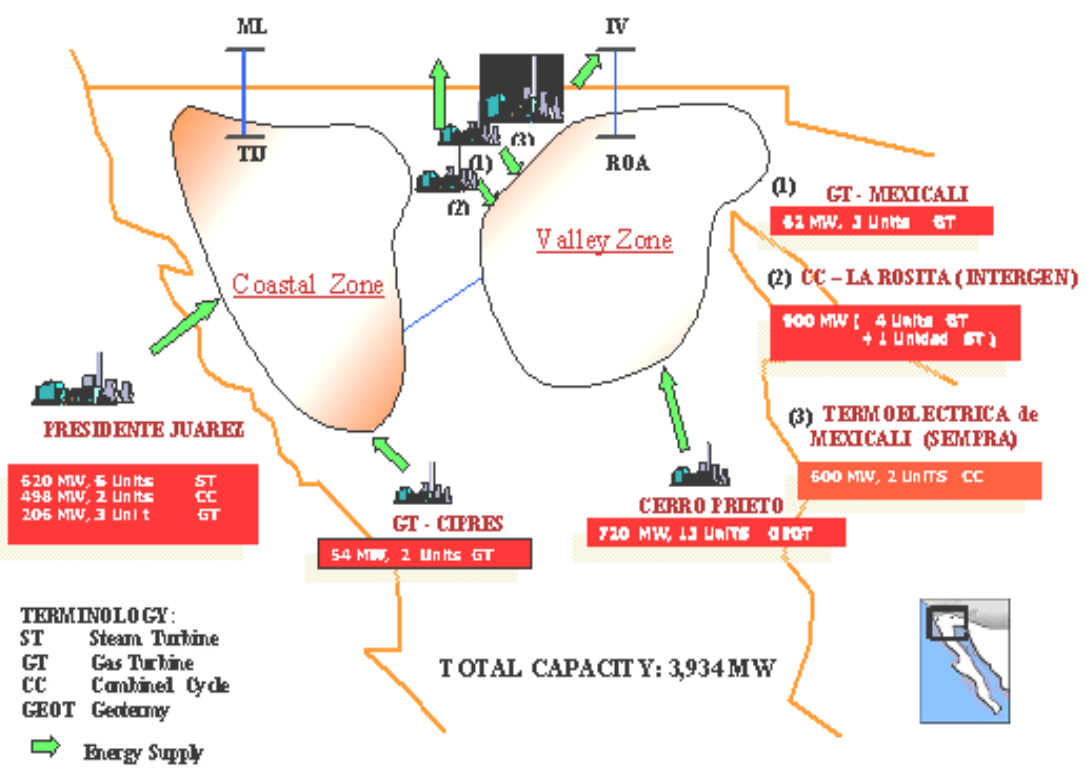

Figure 3: Power generation in Baja California.

The only source of native energy utilized at a big scale is geothermic and the power plant is located at Cerro Prieto, south of Mexicali. It has a plate capacity of 720 MW. The President Juarez Central Power Plant produces 1,330 MW and it is located at the municipality of Rosarito. In addition of these two power plants, above mentioned and the combined cycle plants in Mexicali (La Rosita y La Termoeléctrica de Mexicali), CFE operates ten back up units, distributed in Tijuana, Mexicali, and El Cipres, with an installed capacity of $384 \mathrm{MW}$ [5].

Although California is more diverse than its neighbor to the south (Mexico), in relation to the primary sources of energy utilized in the generation of electricity still the power production does not meet its demand.

Historically, electricity consumption in San Diego has grown an average of $2.8 \%$ per year and peak demand has grown by $3.1 \%$ per year. There has been a steady increase in per capita electricity consumption over the last two decades. Current trends indicate that electricity peak demand will nearly double, increasing by more than $4,000 \mathrm{MW}$ by 2030 . This increase in demand is the equivalent to the output of about six to seven modern generation plants [6].

Imperial County, neighboring Mexicali, has a power infraestructure that makes it autonomous: a thermoelectric generation system that uses natural gas, 512.1 MW capacity; the hydro generation system with 74.8 MW, both for internal consumption; and finally it has several geothermoelectric power plants, $519 \mathrm{MW}$, and 3 thermal power plants, 79 MW capacity each, which production is basically for exportation. 


\section{The growth of future demand}

To respond to the future demand of electricity in the CA-BC binational region various alternatives have been discussed such as the generation of more energy in the region, the increase of the importation of electricity from other regions, and the reduction of the demand by a more efficient use and consumption or a combination of these strategies. For Baja California, to generate more electricity may imply to increase the existing capacity that currently generates 3,934 MW. It is important to note that the State can only import small amounts of electricity from the south of California and Arizona, since it is disconnected from the national electricity grid.

A few years ago the construction and operation of a series of power generating plants in the California and Baja California region was proposed. Some plants are in operation, others are in the process of construction, while some others are in the planning process. In total, these plants will add 3,500 MW to the actual power generating system in the bi-national region [4].

Only in Baja California plans by CFE (see Table 1) anticipate between April 2110 and April 2013, the operation of 5 new power plants that will increase the capacity to $994 \mathrm{MW}$.

Table 1: Future projects for electric power generation and transmission in Baja California.

\begin{tabular}{|c|c|c|c|}
\hline Date & Name & Type & $\begin{array}{c}\text { Capacity } \\
\text { in MW }\end{array}$ \\
\hline April 2010 & Baja California Norte II & Gas Turbine & 234 \\
April 2011 & Baja California III & Combined Cycle & 255 \\
April 2012 & Baja California IV & Gas Turbine & 255 \\
April 2013 & Baja California V & Combined Cycle & 250 \\
\hline
\end{tabular}

/repowering

\begin{tabular}{|c|}
\hline Projects of future transmission \\
Increase in capacity of interconexion south-north from 800 to $2000 \mathrm{MV}$
\end{tabular}

Much of the public policy and regulation decisions affecting the State of Baja California are made outside Baja California especially when it involves the construction of new power plants in the region.

\section{The effects on the environment}

In spite of the obvious benefits of electricity supply, its generation constitutes a sector that utilizes natural resources (oil, coal, natural gas, water), with great repercussions on the environment. Electricity generation produces high amounts of carbon dioxide $\left(\mathrm{CO}_{2}\right)$, nitrogen oxides $\left(\mathrm{NO}_{\mathrm{x}}\right)$, sulphur dioxide $\left(\mathrm{SO}_{2}\right)$, ozone $\left(\mathrm{O}_{3}\right)$ mercury $(\mathrm{Hg})$ and fine particulates, amongst the most important compounds $[1,7]$. 
The Commission of Environmental Cooperation (CEC) of North America published in January 2004, the first report with data of comparable emissions of more than 1000 electricity power plants using fossil fuel in Canada, USA and Mexico [8]. The investigation concluded that a small percentage of power plants generate a great deal of the emissions of sulphur dioxide, mercury and carbon dioxide in North America.

It is important the awareness of atmospheric pollution transportation across the national borders [1]. For example, the ozone and the particular matter generated in Mexicali, Baja California, travels to the other side of the border affecting Imperial Valley, and California mostly when the flow of dominant air comes from the southeast. On the contrary, when the wind flows from the northwest to southeast, which is the most common pattern in the region, these two pollutants come from Imperial Valley to Mexicali [9].

The two plants that recently have been activated in Mexicali (see table 2) utilize natural gas as a source of combustion. When both plants operate at maximum capacity, it is estimated that the potential emissions of La Rosita (intergen, $1060 \mathrm{MW}$ ) and La Termoeléctrica de Mexicali (Sempra, $600 \mathrm{MW}$ ) will be of 2,094 tons of $\mathrm{NO}_{\mathrm{x}}, 2,281$ of $\mathrm{CO}$ and 1,094 of $\mathrm{PM}_{10}$.

Table 2: $\quad$ Emissions to the atmosphere from La Rosita and La Termoeléctrica de Mexicali power plants (tons/year).

\begin{tabular}{|l|l|l|r|}
\hline Power Plant & CO & NOx & $\mathrm{PM}_{10}$ \\
\hline $\begin{array}{l}\text { La Rosita } \\
(1060 \mathrm{MW})\end{array}$ & 2,100 & 1,907 & 857 \\
\hline $\begin{array}{l}\text { Termoeléctrica } \\
\text { de Mexicali }\end{array}$ & 181 & 187 & 237 \\
\hline Total & 2,281 & 2,094 & 1,094 \\
\hline
\end{tabular}

\section{The case of two thermoelectric power plants: La Termoelectrica de Mexicali (Sempra) and La Rosita (Intergen)}

Amongst the regions that have not complied with the NAAQS for a given pollutant $\left(\mathrm{PM}_{10}\right.$ and $\left.\mathrm{NOx}\right)$ are the Imperial and Mexicali Valleys [3]. A nonattainment area is subject to requirements of extreme cleanness that if not observed may face sanctions. However, Imperial Valley may not fall in this category if it shows that in spite of having taken all the actions at reach and within its jurisdiction, have not been able to comply with the requirements due to external emissions from Baja California, Mexico. This is the main defense argument of the Imperial County, as Mexicali contributes substantially to the air quality problem of the region, since both are part of the same airshed.

Therefore the sitting of industries, as much as new fixed sources of emission in Mexicali affect negatively the efforts by Imperial Valley to adjust the levels of emissions up to NAAQS. Such is the case of the thermoelectric power plants, 
La Rosita and La Termoelectrica de Mexicali that have contributed more to the deterioration of the air quality of the region.

Having they been built up in Imperial Valley, both power plants would have had to comply with at least three federal requirements that are applied to nonattainment regions: 1) trade off the new emissions with equivalent reductions from local sources; 2) adopt stricter methods of environmental control, to guaranty the lowest emission of pollutants and 3) certify that other installations of the same corporative are in compliance with the same norms in relation to air pollution.

By being sited in Mexicali, La Rosita and La Termoeléctrica de Mexicali have avoided at least two of the three requirements previously mentioned, therefore their operation south of the border has caused a bi-national environmental conflict that involved the USA Supreme Court. Undoubtedly Mexicali and the Imperial Valley share the same airshed. However, they do not count with common and coordinated tools and mechanisms of environmental management to solve these problems.

\section{Mechanism of binational environmental management}

The treaties signed by both countries in issues of environmental cooperation, for instance, The La Paz Agreement, as much as the Border XXI and later the Border 2012 Programs, have set the model towards the mechanisms of transborder collaboration and planning, such as The Joint Advisory Committee for the Improvement of Air Quality in the Paso del Norte Region (comprehend Ciudad Juárez, Chihuahua /El Paso, Texas / Doña Ana County, New Mexico Air Basin (established in 1996)).

The binational management mechanism proposed in this article does not consider necessarily the creation of new institutional structures, it recommends the adoption of models, procedure or methods that allow the articulation of actual institutions to facilitate the cohesion and compatibility of functions and policy.

Some of many initial purposes of this binational mechanism engaged in the air quality management at the Baja California-California Border are:

1. Compile a base text to celebrate an agreement or an specific pact of collaboration for the improvement of the air quality of this region

2. Define and rule the structure of the mechanism as much as its operation

3. Manage the official recognition of the international airshed of the region, which leads to define a transborder territorial limit

4. Elaborate a shared diagnosis of the environmental problem of the region

5. Formulate policies, plans and program adequate to the normativity of each country and focused on the reality of the the region

6. Develop and apply procedures to evaluate the transborder environment

7. Implement schemes of transborder emissions commercialization

8. Manage a joint growth of the border region, according to the principles of sustainable development 
9. Induce the application of the prevention principle of pollution and include, during the processes of planning, the aspects of environment and give them the same importance than the economic and social ones, by implementing the strategic environmental assessment.

10. Use of Best Available Technology (i.e. dry cooling system for deserted areas like Mexicali and Imperial and net zero emissions)

\section{An alternative procedure of environmental assessment}

In parallel with the creation, development and implementation of the binational mechanism of the common atmospheric airshed, it is proposed the adoption of a form of evaluation of the effects to the environment produced by the projects of electricity generation, particularly those that will be built at the border region currently under analysis, having them passing from a mechanism of assessment by project to one more integral and systemic evaluation, that gives value to environmental repercussions in plans and programs.

From the beginning, the promulgation of the National Environmental Law of the USA, that was approved on January 1st 1970, the purpose of the Environmental Impact Assessment (EIA) is to evaluate the effects of a given project, and point out possible measures of mitigation, remediation or compensation [10].

For years, the EIA has revealed its strength as an instrument of environmental policy that helps to consider and up to a point avoids damages to the environment derived from specific projects, but nonetheless the experience has allowed also to know the limitations of a system of evaluation confined only to the stage of plans, within a cycle of planning much wider and complex. Thus, when realizing the evaluations of a project it is observed that this may or not cause significative damages, but if the future programs are considered in the same region, then will be noticed that the combination or synergy of the individual effects may be important.

Then comes out the need to include the environmental considerations in the planning process of the economic development. In this respect, appears the Strategic Environmental Assessment (SEA) as an option that integrates the environmental with the social and economic policies. If both sides of the border are included from the start it may be called the Strategic Transborder Environmental Assessment (STEA)

The SEA implies [11] the environmental evaluation taken to the level of the policies, plans and programs. It pretends to be more than a complement to the environmental impact assessment of projects, which establishes a general frame to consider its evaluation. Some of the points to be considered are: accumulative effects, reduction of GHG, conservation of resources and sustainability. The SEA may be contemplated as a long-term vision of sustainable development in the future, which may be integrated in the strategic decisions of the public administration.

Before the imminent arrival of infraestructure, for the generation of electric energy in the $\mathrm{BC}-\mathrm{CA}$ border region, which is already arriving and it will 
increase, it is important to consider the environmental repercussions in the early decision making. Particularly, without downgrading their implications in the air quality of a transnational atmospheric airshed with important signs of degradation.

\section{Conclusions}

Baja California seems to be designated to become the preferred region for the arrival of new investments to generate electricity and liquified natural gas terminals. This scenario might be favored by the laxitud in the normativity and environmental procedures in Mexico, respect to those in the USA

One of the most important projects where work should be done is in the establishment of a Strategic Transborder Environmental Assessment (STEA) in benefit of the sustainable development of the CA-BC border region, to face the challenges that impose the reduction of the atmospheric pollution and its effect on health, especially those related to power generation. The significance of this proposal is to establish a mechanism of binational environmental management, through a wide public participation and a solid variety of instruments, strategies and joint actions.

\section{References}

[1] Vaughan, S., Z. Patterson, P. Miller, and G. Block.. Retos y oportunidades ambientales en el dinámico mercado de electricidad de América del Norte. Comisión para la Cooperación Ambiental de América del Norte. Canadá. Documento de Trabajo. http://www.cec.org. 2002

[2] Powers, B.. Energy, the environment, and the California-Baja California border region. Vol. 18, Issue 6. The Electricity Journal. pp 77-84 2005

[3] Quintero, N. M. and Sweedler, A. Air quality evaluation in the Mexicali and Imperial Valleys as an element for an outreach program, in Collins, K., Ganster, Mason, C., Sánchez, L.E., and Quintero N.M. (Eds.). Imperial-Mexicali Valleys: development and environment of the U.S.Mexican border region, SDSU Press and IRSC, U.S.A., pp 263-280. 2004.

[4] Sweedler, A., M. Quintero, and K. Collins.. Energy issues in the U.S.Mexican binational region: focus on California-Baja California. In The US-Mexican border environment: trade, energy, and the environment: challenges and opportunities for the border region, now and in 2020. SCERP Monograph Series, Number 7, David Rohy, Ed., SDSU Press. Pp 57-104. 2003.

[5] CFE. Generación de energía eléctrica. http://whttp://www.cfe.gob.mx/es /LaEmpresa/queescfe/Estadísticas/. 2009

[6] Sandag, http://www.sandag.org/uploads/publicationid/publicationid_1383 8418.pdf 2009.

[7] Miller, P., Z. Patterson, and S. Vaughan. Estimating future air pollution from new electric power generation. Commission for Environmental 
Cooperation of North American. Canada. Working Paper. http://www.cec.org. 2002.

[8] Miller P. and Van Atten. Emisiones atmosféricas de las centrales eléctricas en America del Norte. Comisión de Cooperación Ambiental de Norteamérica. 2004.

[9] Chow, J.C., et al. Imperial Valley/Mexicali cross border PM10 transport study. Draft Final Report. Reno: Desert Research Institute, University and College System of Nevada. 1995.

[10] Pardo, B. M.. La evaluación del impacto ambiental y social para el siglo XXI; técnicas, procesos, metodología. Editorial Fundamentos. Primera Edición, Madrid, España. 2002

[11] Gilpin, A. An environmental impact assessment: cutting edge for the twenty-first century. Cambridge University Press. 1995 